\title{
Long-Term Changes in Water Quality and Eutrophication of China's Liujiang River
}

\author{
Baiyang Jiang1,2, Jianhua Chen ${ }^{3}$, Qiqing Luo ${ }^{4}$, Junxiang Lai', \\ Huixin $\mathrm{Xu}^{6}$, Yinghui Wang ${ }^{1 *}$, Kefu Yu${ }^{1 * *}$ \\ ${ }^{1}$ School of Marine Sciences, Guangxi University, Nanning 530004, China \\ ${ }^{2}$ School of Environment, Guangxi University, Nanning 530004, China \\ ${ }^{3}$ School of Resources and Metallurgy, Guangxi University, Nanning 530004, China \\ ${ }^{4}$ The Department of Science and Technology, Guangxi University, Nanning 530004, China \\ ${ }^{5}$ Guangxi Academy of Sciences, Nanning 530007, China \\ ${ }^{6}$ Water Conservancy Bureau of Liuzhou City, Liuzhou 545000, China
}

Received: 2 December 2015

Accepted: 16 February 2016

\begin{abstract}
Long-term changes (2003-14) of water temperature, $\mathrm{DO}, \mathrm{pH}, \mathrm{TN}, \mathrm{NH}_{4}-\mathrm{N}, \mathrm{TP}$, and $\mathrm{COD}_{\mathrm{Mn}}$ were examined at eight sampling stations along the Liujiang River. Water quality parameters showed considerable spatial and temporal variability. Annual averages of those parameters were $22.1^{\circ} \mathrm{C}, 7.8 \mathrm{mg} / \mathrm{L}, 7.58,1.35 \mathrm{mg} / \mathrm{L}$, $0.27 \mathrm{mg} / \mathrm{L}, 0.06 \mathrm{mg} / \mathrm{L}$, and $1.7 \mathrm{mg} / \mathrm{L}$, respectively. An increasing trend for TN/TP and a decreasing trend for $\mathrm{pH}$ were observed in all parts of the Liujiang. Pollution levels were generally higher in the lower Liujiang than in the upper and middle parts of the river due to the impact of urban sewage. All indicators reached level III water quality standards except TN, which suggests that the control of nitrogen emissions should be strengthened. Relatively high N/P ratios in the Liujiang contribute to a potential for phosphorus limitation of phytoplankton. The average concentration of Chlorophyll- $a$ was $1.2 \mu \mathrm{g} / \mathrm{L}$ in 2014 . The TLI index indicated that the eutrophication state of the Liujiang was mesotrophic, while the downstream water was polluted due to its nutrient inputs from agriculture and urban sources. The water quality of the river keeps well by comparison to other major rivers of the world, which provided the basis for urban development and river protection in Liuzhou City.
\end{abstract}

Keywords: Liujiang River, riverine reservoir, water quality, eutrophication, nutrients 


\section{Introduction}

Many studies have indicated that human activities have the potential to change water environments [18]. Eutrophication is the most obvious environmental water problem in recent years worldwide [9-12]. As a consequence of increasing populations, plus industrial and agricultural development and urbanization, increases of nitrogen and phosphorus entering reservoirs and rivers has led to increased concerns about eutrophication [13-17]. Meanwhile, in order to utilize water resources effectively (such as reducing flood risk and producing hydropower energy), plentiful reservoirs with large water retention capacity were built in China [18]. But most of them showed a rapid increase in eutrophication and deteriorating water quality after impoundment due to the hydrodynamic conditions and significant changes from the natural state with slower water velocity and longer residence time $[19,20]$.

The Liujiang River is one main tributary in the Pearl River, which is the largest river in southern China. It snakes through Liuzhou, a large city in the Guangxi Zhuang Autonomous Region (GXZAR), from northwest to southeast, and originates from Guizhou with a total length of $772 \mathrm{~km}$ and an annual average discharge of $1,865 \mathrm{~m}^{3} / \mathrm{s}$ and a drainage area of $58,398 \mathrm{~km}^{2}$ [21]. In consideration of the abundant water resources of the Liujiang River basin, nine cascade hydropower stations were built successively, and Honghua Reservoir is the last one, just on the outskirts of Liuzhou. After Honghua stored water at the end of 2005, the water level of the Liujiang River section in Liuzhou was raised 4 to $5 \mathrm{~m}$, reaching $77.5 \mathrm{~m}$. By providing convenient, inexpensive water traffic for the transportation of goods from Liuzhou Port to Guangzhou Port, the Liujiang has played a significant role in the economy between the GXZAR and Guangdong - one of the most prosperous districts in southern China.

Liuzhou City is the largest industrial city and economic center of GXZAR, and an industry base in southwestern China, having formed a complete industry system dominated by automobile, machinery, and metallurgy, and supported by chemical industry, sugar refining, paper making, medicine, building material, and chemical, etc. [22]. However, the high-paced development of manufacture in Liuzhou has imposed a heavy burden on the Liujiang and has had an adverse impact on its habitat. More importantly, the main stem of the Liujiang is the sole

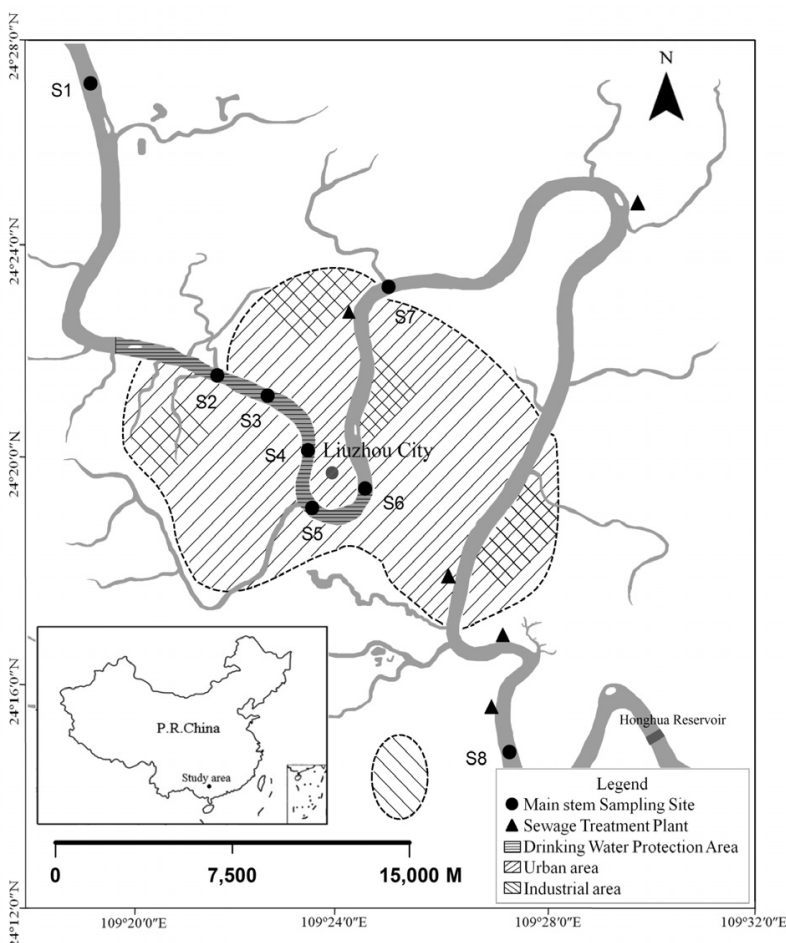

Fig. 1. Locations of sampling sites in the main stem of the Liujiang River in Liuzhou City.

receiving water body for treated and untreated wastewater in Liuzhou via tributaries and the sewage systems [23].

Therefore, the Liujiang River faces the threat of eutrophication, which could potentially affect industrial production and living standards. However, to date there have been few studies on the occurrence of eutrophication in the Liujiang section of Liuzhou, the most important source of drinking water for this region.

The objective of this study is to explore the eutrophication factors (regulatory surveys and nutrients) on the river course (74-km long) over a period of 12 years (2003-14) in the mainstream of the Liujiang River section of Liuzhou. The following tasks were performed:

1) Access water quality.

2) Understand the spatial-temporal distribution of nutrients, especially nitrogen $(\mathrm{N})$ and phosphorus $(\mathrm{P})$.

3) Determine the eutrophication level of the Liujiang River.

Table 1. Environmental quality standards for surface water (GB3838-2002) in China: classification and standard values for basic nutrient parameters.

\begin{tabular}{|c|c|c|c|c|c|c|c|}
\hline $\begin{array}{l}\text { Threshold value } \\
\text { of water standard }\end{array}$ & $\begin{array}{l}\text { WT } \\
\left({ }^{\circ} \mathrm{C}\right)\end{array}$ & $\mathrm{pH}$ & $\begin{array}{c}\mathrm{DO} \\
(\mathrm{mg} / \mathrm{L})\end{array}$ & $\begin{array}{l}\mathrm{COD}_{\mathrm{Mn}} \\
(\mathrm{mg} / \mathrm{L})\end{array}$ & $\begin{array}{l}\mathrm{NH}_{4}-\mathrm{N} \\
(\mathrm{mg} / \mathrm{L})\end{array}$ & $\begin{array}{c}\mathrm{TN} \\
(\mathrm{mg} / \mathrm{L})\end{array}$ & $\begin{array}{c}\mathrm{TP} \\
(\mathrm{mg} / \mathrm{L})\end{array}$ \\
\hline I & - & \multirow{4}{*}{$6-9$} & 7.5 & 2 & 0.15 & 0.2 & 0.02 \\
\hline II & - & & 6 & 4 & 0.5 & 0.5 & 0.1 \\
\hline III & - & & 5 & 6 & 1.0 & 1.0 & 0.2 \\
\hline IV & - & & 3 & 10 & 1.5 & 1.5 & 0.3 \\
\hline
\end{tabular}


The results will provide useful information for controlling nutrient emissions and water quality management in the Liujiang.

\section{Materials and Methods}

\section{Study Area and Sampling}

The length of the Liujiang in Liuzhou is $74 \mathrm{~km}$, with a drainage area of $538 \mathrm{~km}^{2}$ and annual average discharge of $875 \mathrm{~m}^{3} / \mathrm{s}$ (2012). Eight water monitoring stations (S1-S8) and the Honghua Reservoir were identified for the study (Fig. 1). The surface water of those stations was sampled monthly (or bi-monthly for some of the variables). Water quality databases, including water temperature (WT), $\mathrm{pH}$, dissolved oxygen (DO), chemical oxygen demand (permanganate) $\left(\mathrm{COD}_{\mathrm{Mn}}\right)$, ammonia nitrogen $\left(\mathrm{NH}_{4}-\mathrm{N}\right)$, total nitrogen (TN), and total phosphorus (TP) were collected from the eight monitoring sites established by the Liuzhou Water Conservation Bureau (LWCB) from 2003 to 2014, but Chlorophyll- $a$ was only monitored in 2014 and the samples for analysis of Chlorophyll- $a$ were taken from January to December at the same eight sampling sites. Water samples for nutrient analysis were kept and analyzed according to the methods in "Environmental quality standards for surface water" (GB3838-2002, China).
The middle of the Liujiang serves as a centralized drinking water supply source and the water quality here should comply with standard III (Table 1), which is mainly suitable for class I protection areas for centralized potable water sources, protection areas for rare fish, and spawning grounds for fish and shrimp (Ministry of Environmental Protection 2002).

\section{Trophic Status Evaluation}

The comprehensive nutrition state index (TLI) was used to evaluate eutrophication levels in different scenarios in order to comprehensively understand water quality and eutrophication levels in the Liujiang [24].

The TLI is given as follows:

$$
\operatorname{TLI}\left(\sum\right)=\sum_{j=1}^{m} W_{j} \cdot T L I(j)
$$

...where TLI ( $\mathrm{j}$ ) is the single eutrophication index for one parameter and $\mathrm{W}_{\mathrm{j}}$ is the relative weight of the single eutrophication index for parameter $\mathrm{j}$.

A series of $0 \sim 100$ consecutive numbers is adopted for grading the eutrophication level: TLI $(\Sigma)<30$, oligotrophic; $30 \leq$ TLI $\left(\sum\right) \leq 50$, mesotrophic; TLI $\left(\sum\right)>50$, eutrophic; $50<\mathrm{TLI}\left(\sum\right) \leq 60$, moderately eutrophic; $60<$ TLI $\left(\sum\right) \leq 70$, moderately high eutrophic; TLI $\left(\sum\right)>70$, highly eutrophic.
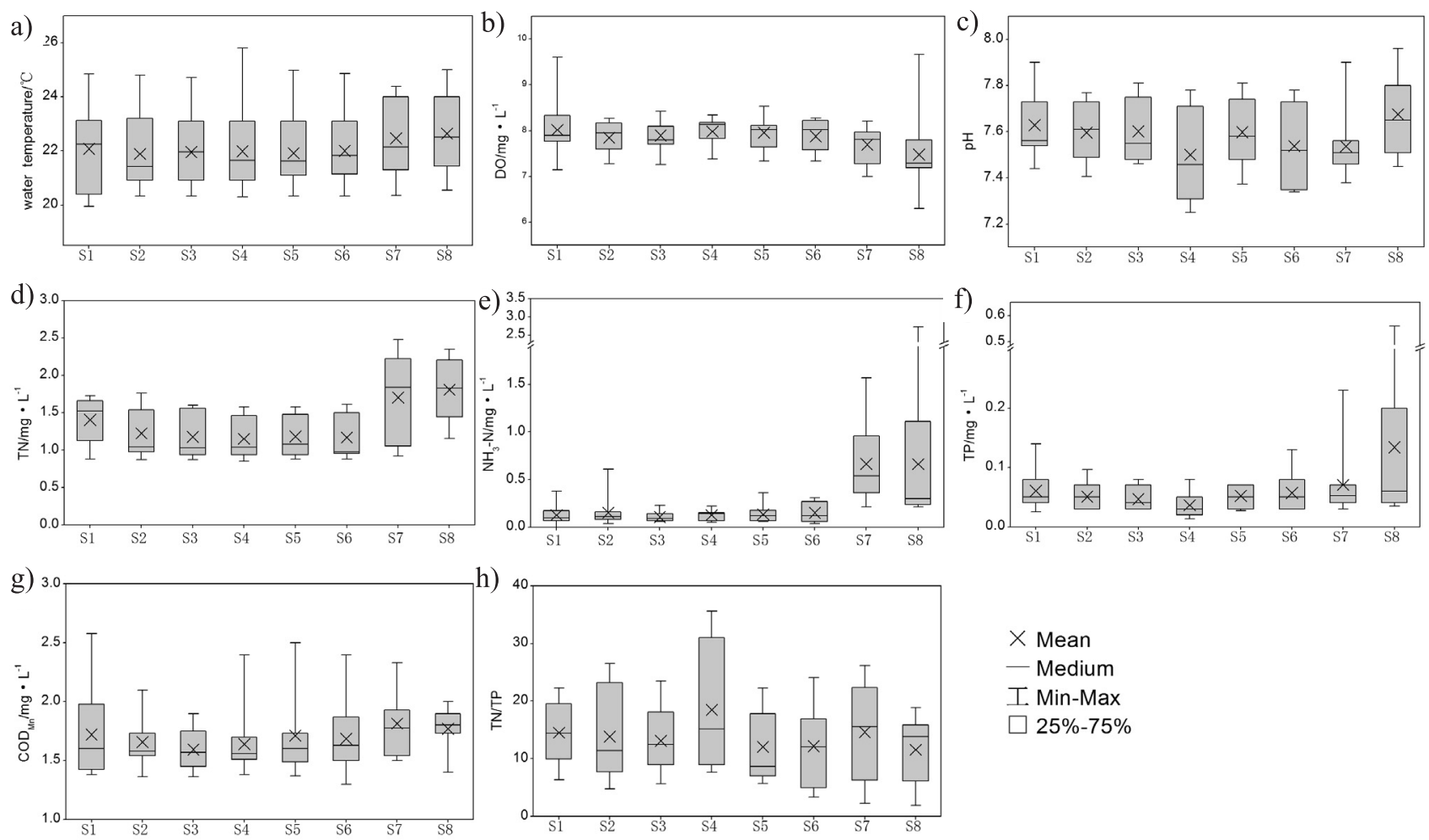

Fig. 2. Boxplots for longitudinal changes in a) water temperature, b) $\mathrm{DO}$, c) $\mathrm{pH}$, d) $\mathrm{TN}$, e) $\left.\mathrm{NH}_{4}-\mathrm{N}, \mathrm{f}\right) \mathrm{TP}$, g) $\mathrm{COD}_{\mathrm{Mn}}$, and h) $\mathrm{TN} / \mathrm{TP}$ concentrations in eight stations from 2003 to 2014. 


\section{Results and Discussion}

\section{Long-Term Spatial and Longitudinal Analysis}

The interannual changes of water temperature, DO, $\mathrm{pH}, \mathrm{TP}, \mathrm{TN}, \mathrm{NH}_{4}-\mathrm{N}, \mathrm{COD}_{\mathrm{Mn}}$, and TN/TP over a period of 12 year at the eight sites are shown in Fig. 2, from which the visualized longitudinal distributions of the parameters of water quality can be readily observed.

Fig. 2a shows that the water temperatures of the eight stations were basically similar, but they increased slightly $\left(+0.5^{\circ} \mathrm{C}\right)$ in $\mathrm{S} 1, \mathrm{~S} 7$, and $\mathrm{S} 8$. This may because S2-S6 were located in the center of Liuzhou, where the river was deep and broad with large storage capacity, while the river channels of S1, S7, and S8 were shallow with small storage capacity.

The annual average value of DO was about $7.80 \mathrm{mg} / \mathrm{L}$ and it can be seen that the values of DO decreased along the river from $8.01 \mathrm{mg} / \mathrm{L}$ (S1) to $7.48 \mathrm{mg} / \mathrm{L}$ (S8) in Fig. $2 \mathrm{~b}$, which demonstrated that the pollution along the shores of the city affected DO gradually. The pollutants in the water column were decomposed with oxygen consumption by the water's self-purification capacity, so the dissolved oxygen levels dropped along the river $[25,26]$. The fluctuation of DO in each position was small, except for $\mathrm{S} 1$ and S8. This phenomenon may be due to the suburban locations of S1 and S8, which were far from the city, and the surrounding influences were complex. But DO in all eight sites conformed to standard II.

The annual mean of $\mathrm{pH}$ was 7.58 (Fig. 2c), and the $\mathrm{pH}$ was weak alkalinity as a whole. However, the $\mathrm{pH}$ in $\mathrm{S} 4$ (the center of the city) was more acidic than in other sites, presumably due to the Liuzhou Chemical Plant located north of S4. This chemical plant is one of the largest chemical fertilizer production enterprises in GXZAR, mainly engaged in synthetic ammonia and nitrogen fertilizer. The long-term effusion of nitrogen fertilizer affects its surrounding environment, including the river. In many studies, overuse of nitrogen fertilizer is a cause of soil acidification [27-30].
The annual average values of $\mathrm{TN}, \mathrm{NH}_{4}-\mathrm{N}, \mathrm{TP}$, and $\mathrm{COD}_{\mathrm{Mn}}$ were $1.35 \mathrm{mg} / \mathrm{L}, 0.27 \mathrm{mg} / \mathrm{L}, 0.06 \mathrm{mg} / \mathrm{L}$, and $1.7 \mathrm{mg} / \mathrm{L}$, respectively. But the concentrations of nutrient parameters $\left(\mathrm{TN}, \mathrm{NH}_{4}-\mathrm{N}\right.$, and $\left.\mathrm{TP}\right)$ in $\mathrm{S} 7, \mathrm{~S} 8$ obviously were higher than the other six sites (Figs 2d, e, f, and h). Presumably, the water in S7 and S8 was contaminated by the treated sewage water from the upriver sewage treatment stations (Fig. 1), and S8 was far away from the city, where the municipal regulation was not so strict as in the city. On the whole, the annual average concentrations of $\mathrm{COD}_{\mathrm{Mn}}$, $\mathrm{NH}_{4}-\mathrm{N}$, and TP in each stations had reached standard III, but the concentration of $\mathrm{TN}$ exceeded this standard. In order to protect the river water quality, the management department of Liuzhou City should strengthen the control nitrogen emissions.

Redfield law says that the ratio of atoms that compose algal cells is $\mathrm{C}: \mathrm{N}: \mathrm{P}=106: 16: 1$; if the molar TN/TP ratio is higher than 16:1, phosphorus should be considered the restrictive factor. Conversely, when the ratio is less than $10: 1$, nitrogen should usually be considered the restrictive factor [31], and this law suits phytoplankton in marine and freshwater lakes. In the Liuzhou, the average molar TN/TP ratio was 13.8 (Fig. 2h), and it fluctuated from 2.0 to 35.0. So phosphorus and nitrogen were the possible restrictive factors at different times in the Liujiang, but it was more inclined to be phosphorus. Under these circumstances, once extra phosphorus was pushed into the river, the outbreak of algal blooms was just around the corner. Nutrient limitation bioassays were needed in order to make sure of the restrictive factor.

\section{Temporal Variations in Water Quality}

The Liujiang was divided into three parts artificially herein: the upper (S1), middle (S2-S6), and lower (S7, S8). This partition was due to the concentrations of nutrient parameters, and the urban Liuzhou was around the middle, while S7 and S8 were downstream of the industrial zone. The interannual variability of three parts in the river are shown in Figs 3 and 4.
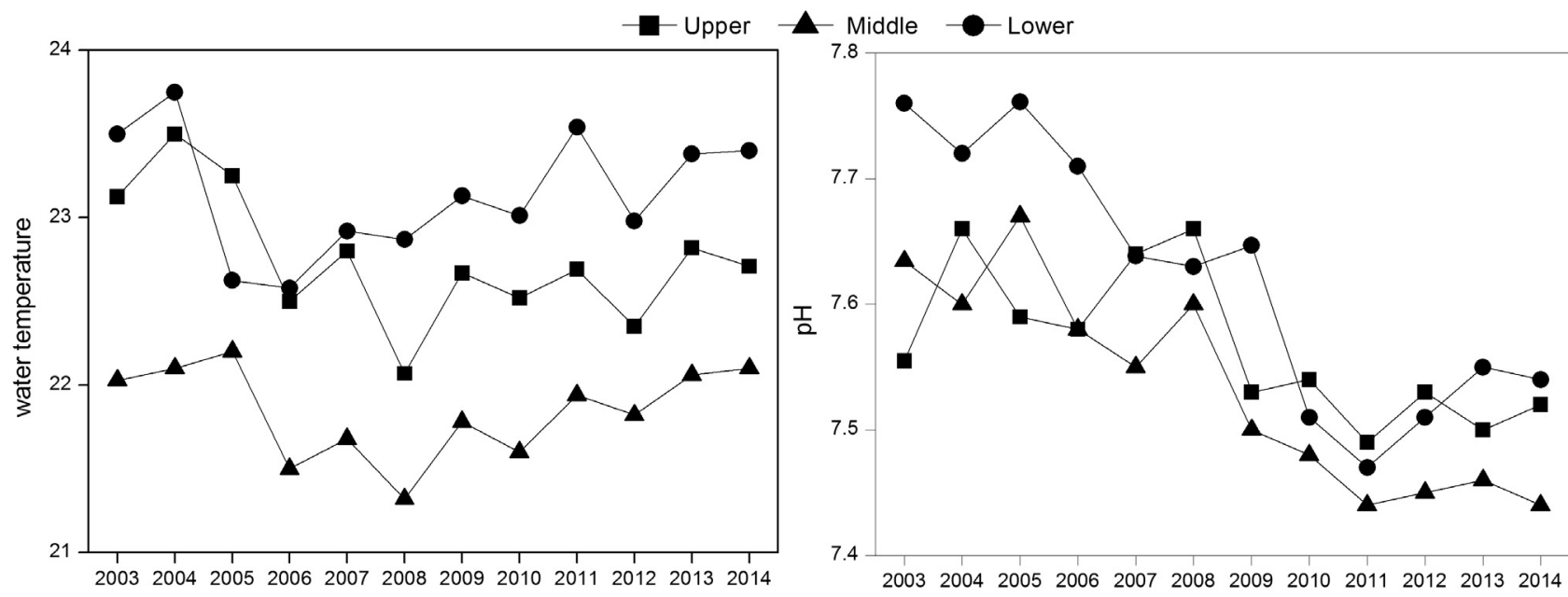

Fig. 3. Interannual variability in water temperature and $\mathrm{pH}$. 


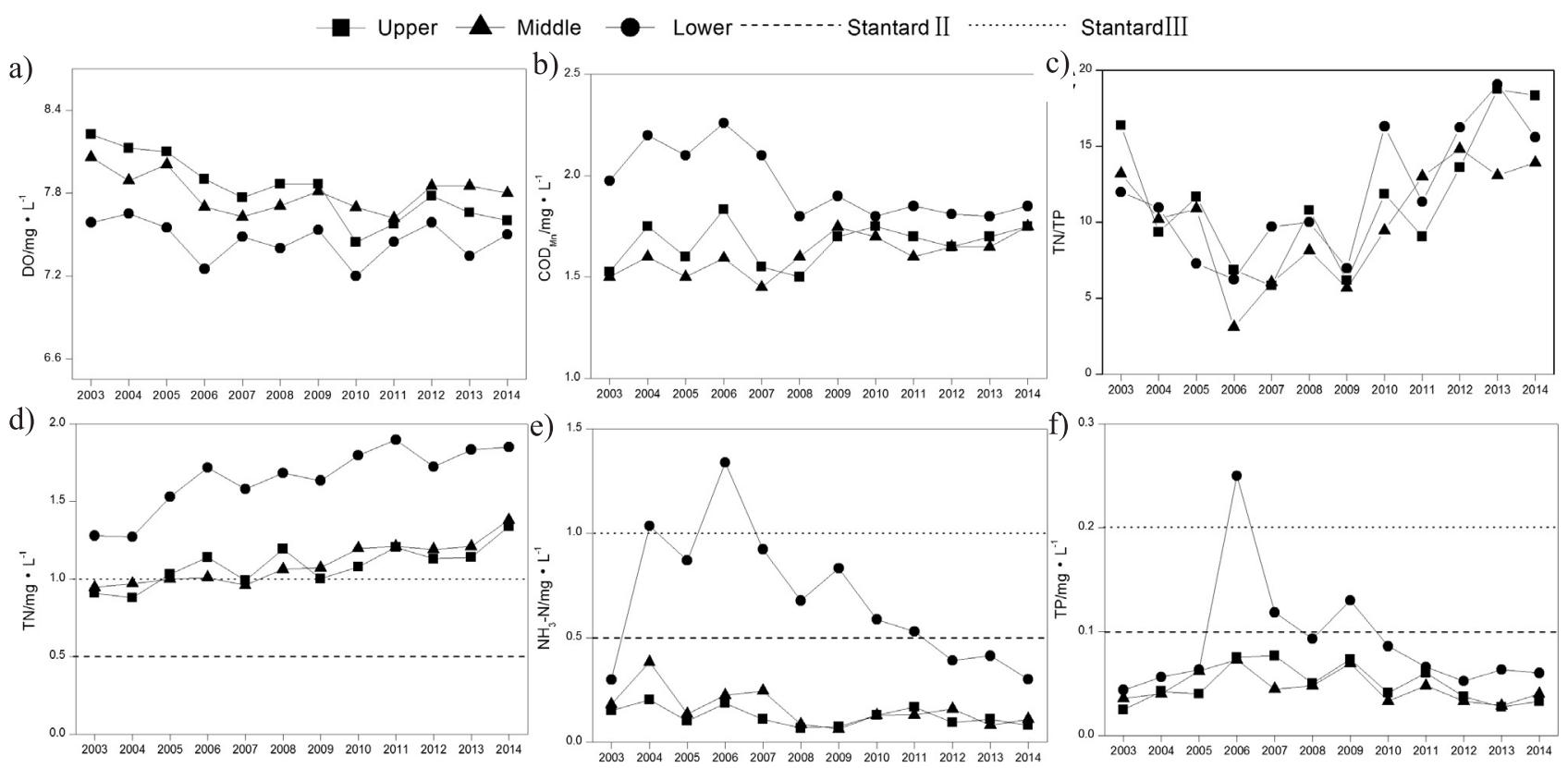

Fig. 4. The interannual variability of a) $\mathrm{DO}, \mathrm{b}) \mathrm{COD}_{\mathrm{Mn}}$, c) TN/TP, d) TN, e) $\mathrm{NH}_{4}-\mathrm{N}$, and f) $\mathrm{TP}$ concentrations in different regions from 2003 to 2014.

\section{Water Temperature and $\mathrm{pH}$}

The annual average water temperature was $22.1^{\circ} \mathrm{C}$, which is suitable for algae growth, and the interannual fluctuations were small in the three river sections (from 21.3 to $23.7^{\circ} \mathrm{C}$ ). But the water temperature in the middle section was obviously lower than the upper and lower sections, which related to water storage capacity. From a temporal perspective, the results indicated a general decline in water temperature in 2006, which may because Honghua Dam was completed downstream at the end of 2005, and then the rising water levels after impoundment and the broad channel area weakened the "heat island effect" of Liuzhou. The lowest annual temperature appeared in 2008, which may be related to the snow disaster in 2008 [32]. On the whole, the water temperature values increased slowly with fluctuation since 2006, which may because that the rapid development of urbanization and quick growth of population leading the urban "heat island effect" was a great influence on temperature.

Acid precipitation or acid rain as a global environmental problem has aroused widespread concern, and in parts of southwestern and southern China acid rain is even more serious [33, 34]. Liuzhou is a typical industrial city in southwestern China that became one of the four "capitals of acid rain" in the 1980s, which also severely affected the Liujiang. The $\mathrm{pH}$ in three sections all had a conspicuous trend of acidification in recent years, though the acidification speed was slow, and this circumstance may be because of the acid waste discharge from Liuzhou industry. The iron and steel industry was the pillar of Liuzhou, and it gave off lots of exhaust gas such as sulfur dioxide, dust, etc., and eventually they formed acid rain and had a significant impact on river $\mathrm{pH}$. In addition, $\mathrm{pH}$ in the lower Liujiang was higher than the middle and upper before 2007, but they turned out to be similar in the following years. In addition to the effects of acid rain, the requirements from government also had effects on river $\mathrm{pH}$, which claimed that industrial wastewater may not be discharged into the river without first reaching the standard.

\section{Nutrients and other Chemical Parameters}

The concentrations of DO didn't show a clear trend over 12 years, and the average DO of the upper, middle, and lower Liujiang were $7.83,7.80$, and $7.46 \mathrm{mg} / \mathrm{L}$, respectively. The whole river reached standard II of $\mathrm{COD}_{\mathrm{Mn}}$, which required concentrations less than $4 \mathrm{mg} / \mathrm{L}$. The interannual changes of $\mathrm{COD}_{\mathrm{Mn}}$ in the upper and middle Liujiang were very little, but it was obvious that the concentrations of $\mathrm{COD}_{\mathrm{Mn}}$ in the lower Liujiang were reduced. The $\mathrm{COD}_{\mathrm{Mn}}$ in the lower Liujiang was always higher than other parts, and in recent years the concentrations of $\mathrm{COD}_{\mathrm{Mn}}$ in three parts were roughly comparable.

Concentrations of nitrogen and phosphorus have changed significantly over time (Figs 4d, e, f). The extent and timing of these changes differ not only between nitrogen and phosphorus, but also between forms of nitrogen. The concentrations of TN in the upper were almost the same as the middle (the average was $1.1 \mathrm{mg} / \mathrm{L}$ ). But in the upper and middle the concentrations of TN exceed water quality standard III (1 mg/L), which didn't appear in other indicators, indicating that the upper Liujiang has been polluted by surplus nitrogen already. Lots of studies have shown that agricultural non-point source pollution was the main nitrogen source of eutrophication in many lakes [3538]. And in the lower Liujiang, the concentrations of TN 
increased a lot (the average was $1.6 \mathrm{mg} / \mathrm{L}$ ). It showed that after running through the urban areas of Liuzhou, where agricultural proportion was less, the Liujiang was polluted by industrial and municipal pollution. From what has been discussed above, the nitrogen pollution of the river has resulted from industry and agriculture.

The average concentrations of $\mathrm{NH}_{4}-\mathrm{N}$ reached water quality standard III in 2007. The reduction illustrated the efforts made to control and reduce $\mathrm{NH}_{4}-\mathrm{N}$ from point sources (wastewater treatment improvements and change in agricultural practices) linked with the Liuzhou government's pollution reduction efforts. In contrast to notable $\mathrm{NH}_{4}-\mathrm{N}$ reduction along the whole river, the concentrations of TP remain stable in the upper and middle Liujiang, but it changed a lot in the lower Liujiang.

$\mathrm{NH}_{4}-\mathrm{N}$ declined on the whole and TP had no obvious trend. But TN appeared to have a higher value in 2006, and the same situation also appeared in $\mathrm{NH}_{4}-\mathrm{N}$ and TP, showing that the concentrations of pollutants apparently increased in 2006. The possible reason for this phenomenon was that Honghua Dam began to impound water at the end of 2005, and then the pollutants in the city were blocked and accumulated until reaching the normal storage level (77.5 meters).

The molar TN/TP ratios didn't vary greatly and showed a trend of dropping from 2003 to 2006 and the lowest ratio appeared in the middle Liujiang in 2006, which was less than 5, showing that nitrogen was sometimes considered the restrictive factor. Actually, the ratio showed a trend of rising after 2006, and phosphorus turned out to be the restrictive factor. So it is necessary to pay attention to nitrogen and phosphorus emissions at the same time, but it is unrealistic to attempt nitrogen load reductions under these circumstances because even if upstream sources are reduced, some algae and bacteria can fix atmospheric nitrogen to biologically available forms [39].

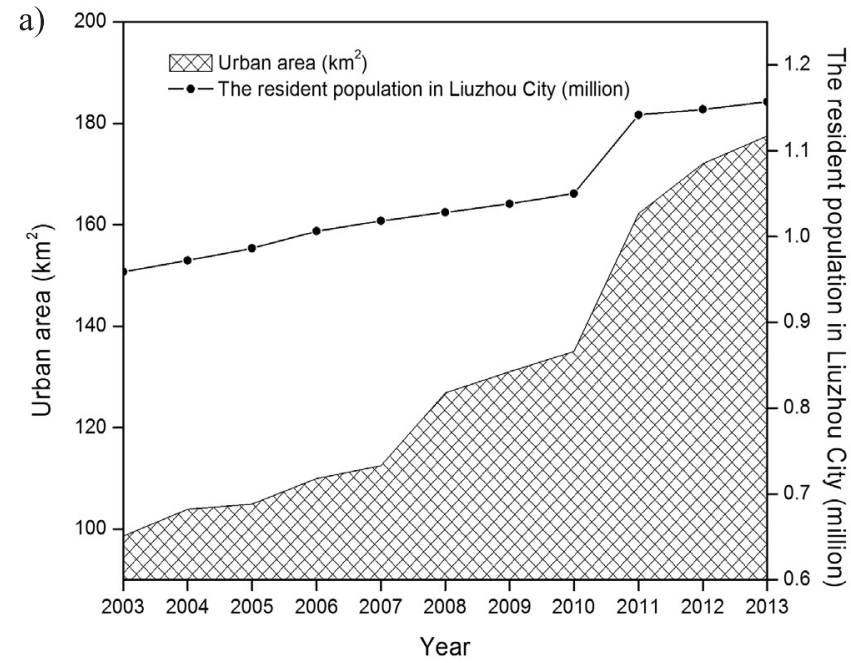

\section{Social and Economic Development and the Relationship with Water Quality}

With the development of a social economy, the economy is increasing and accelerating the urbanization process, and at the same time the population continues growing. These cases are causing sustained growth in emissions of urban sewage, garbage, water loss, soil erosion, and chemical fertilizer in agricultural activities. Eventually they lead to water environment deterioration and a decline in water quality.

With the rapid development of social economy in recent years, urban pressures in Liuzhou city are significant: $1.157 \times 10^{6}$ equivalent inhabitants (2013) were mainly concentrated near the middle of the main river course, about an increase of 0.2 million over 2003. Average annual growth was about $1.9 \%$, and average density of population in 2013 reached 1,000 per $\mathrm{km}^{2}$, which was higher than the first level of population density (100 per $\left.\mathrm{km}^{2}\right)$, belonging to high-density areas. At the same time, the city scale of Liuzhou was quickly expanding, especially after 2007, when it increased from $98.65 \mathrm{~km}^{2}(2003)$ to $177.54 \mathrm{~km}^{2}$ (2013), or about 1.8 times, and average annual growth is about $6.2 \%$. These figures pose serious threats to the Liujiang River environment (Fig. 5). The regional gross domestic product (GDP) in Liuzhou showed a trend of sustained growth, with GDP in 2013 of about 20.1 million RMB, which was 5.56 times the 2003 figure. Average annual growth is about $18.8 \%$, and the GDP per capita in 2013 was some 52,000 RMB. Liuzhou had become one of the cities with the highest economic development levels in Guangxi.

Correlation analysis of the socio-economic development and aquatic environment data during 2003-13 showed that the rapid growth of the GDP and population significantly led to the changes of $\mathrm{pH}$ and $\mathrm{TN}$, which points to the likelihood that pollutant emissions

Fig. 5. Changes of population and urbanization a) and the variation of GDP b) in Liuzhou City during 2003-13 (data in 2014 not available).

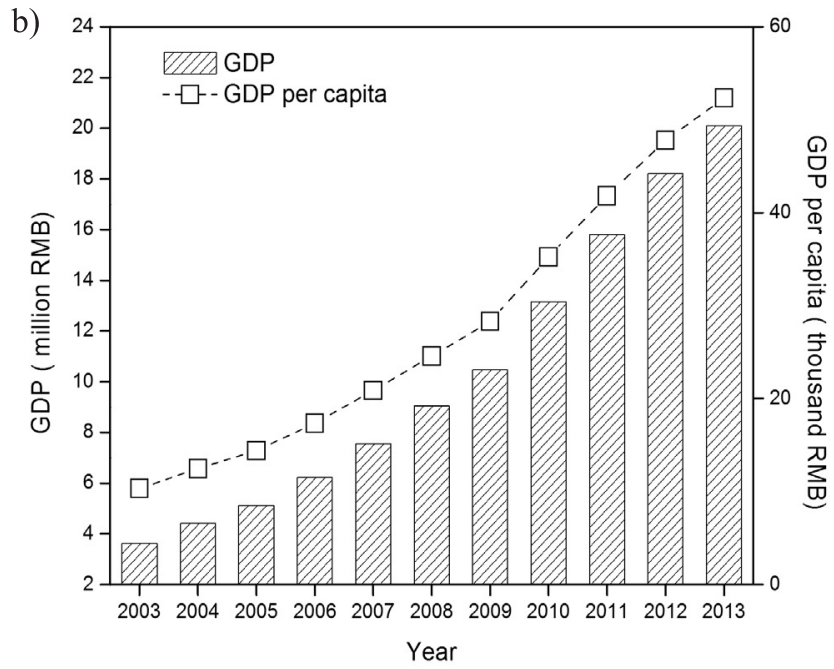


Table 2. The correlation analysis of socio-economic development and aquatic environment of the Liujiang River.

\begin{tabular}{|c|c|c|c|c|c|c|c|c|c|c|}
\hline & & GDP & Population & $\begin{array}{l}\text { Water } \\
\text { temperature }\end{array}$ & DO & $\mathrm{pH}$ & $\mathrm{COD}_{\mathrm{Mn}}$ & $\mathrm{TN}$ & $\mathrm{NH}_{4}-\mathrm{N}$ & $\mathrm{TP}$ \\
\hline \multirow{2}{*}{ GDP } & $\begin{array}{l}\text { Pearson } \\
\text { Correlation }\end{array}$ & 1 & $0.979 * *$ & -0.167 & -0.581 & $-0.925 * *$ & -0.256 & $0.840^{* *}$ & -0.597 & -0.277 \\
\hline & $\begin{array}{c}\text { Sig. } \\
\text { (2-tailed) }\end{array}$ & & 0 & 0.623 & 0.061 & 0 & 0.448 & 0.001 & 0.052 & 0.410 \\
\hline \multirow{2}{*}{ Population } & $\begin{array}{c}\text { Pearson } \\
\text { Correlation }\end{array}$ & $0.979 * *$ & 1 & -0.151 & -0.552 & $-0.912 * *$ & -0.243 & $0.848^{* *}$ & -0.540 & -0.227 \\
\hline & $\begin{array}{c}\text { Sig. } \\
\text { (2-tailed) }\end{array}$ & 0 & & 0.658 & 0.078 & 0 & 0.471 & 0.001 & 0.086 & 0.503 \\
\hline
\end{tabular}

**.correlation is significant at the 0.01 level (2-tailed)

*.correlation is significant at the 0.05 level (2-tailed)

were one important factor affecting water environment security (Table 2). Additionally, this seems to imply that the limited environmental capacity of the Liujiang and the rapid development of the social economy constituted a basic contradiction. But the other indicators didn't have significant correlation, which indicated that Liuzhou can keep river water quality while enjoying socio-economic development. This may relate to the effective control of government, observing sewage discharge standards for companies, and supervising the public.

For example, according to the Liuzhou yearbook, a special fund for environmental protection of the Liujiang wasused to supportcomprehensive environmental pollution treatment from 11.165 million Yuan in 2004 to 16.28 million Yuan in 2005. Environmental law enforcement was strengthened and on-site inspections were carried out 2,583 times in 2003 and 3,975 times in 2010. At the same time, environmental protection information and education was enhanced, and environmental complaints from citizen increased from 1,982 incidents in 2005 to 4,653 times in 2011. As for environmental supervision and management, there were 1,520 environmental projects approved by the protection authority in 2003, including 193 million Yuan in environmental protection investment, and this total reached 2.737 billion Yuan in 2009.

\section{Comparison of Nutrients with Major Rivers}

In the study, we compared nutrients data in the Liujiang to domestic and some foreign major rivers (Table 3). The results show that the contents of $\mathrm{COD}_{\mathrm{Mn}}, \mathrm{NH}_{4}-\mathrm{N}, \mathrm{TP}$, and $\mathrm{TN}$ in the Liujiang was at low levels for all rivers listed, demonstrating its good river quality. From Table 3, the domestic rivers showed a trend of high nitrogen and low phosphorus as a whole. In this way, most of the rivers, including the Liujiang, were phosphorus limited for the past few years.

In the comparison, the Liujiang was similar than the Danube in the indicators of $\mathrm{COD}_{\mathrm{Mn}}$ and $\mathrm{NH}_{4}-\mathrm{N}$. And it was comparable with the Lorie River in the indicators of TP and TN. The Danube and Lorie are both in Europe, which is a developed area. Then after the development of

Table 3. Comparison of the Liujiang River with major rivers of the world.

\begin{tabular}{|c|c|c|c|c|c|c|}
\hline River & $\mathrm{COD}_{\mathrm{Mn}}$ & $\mathrm{NH}_{4}-\mathrm{N}$ & TP & $\mathrm{TN}$ & Year & Reference \\
\hline Eastern rivers in Taihu lake & 4.42 & 0.29 & 0.11 & 2.48 & 2008 & {$[40]$} \\
\hline $\begin{array}{l}\text { Major input rivers of Three Gorges } \\
\text { Reservoir } \\
\end{array}$ & - & $0.07-0.28$ & $0.12-0.29$ & $1.55-2.15$ & 2004-2005 & {$[41,42]$} \\
\hline Fenhe River in Taiyuan & 23.95 & 35.49 & - & - & 2007 & {$[43]$} \\
\hline Xiangjiang River in Changsha & 2.39 & 0.51 & - & - & $2002-2005$ & {$[44]$} \\
\hline Zhujiang River in Guangzhou & 7.88 & 8.63 & - & - & 2007 & {$[45]$} \\
\hline Danube & $1.7-5.3$ & $\begin{array}{c}0.021- \\
0.387 \\
\end{array}$ & - & - & 2003 & {$[46]$} \\
\hline The Thames Tributary & - & $1.1-2.1$ & - & - & 1997 & {$[47]$} \\
\hline Marne & - & - & 0.04 & 7 & 1991-2001 & [48] \\
\hline Lorie & - & - & 0.06-0.09 & $1.0-2.0$ & 1981-2011 & [49] \\
\hline Liujiang River in Liuzhou & 1.7 & 0.27 & 0.06 & 1.35 & $2003-2014$ & this paper \\
\hline
\end{tabular}



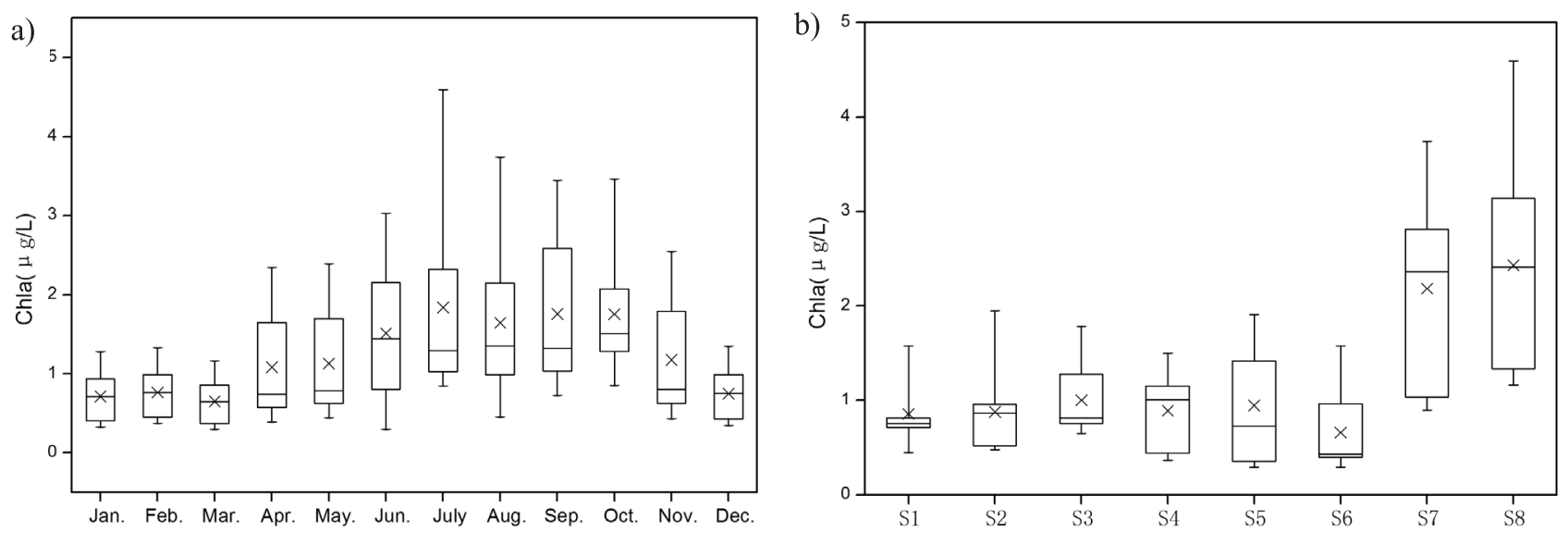

Fig. 6. Boxplots for monthly a) and longitudinal b) changes of Chlorophyll-a ( $\mu \mathrm{g} / \mathrm{L})$ in 2014.

Liuzhou, whether or not Liujiang water quality can remain high remains unknown.

\section{Chlorophyll- $a$ and Nutritional Status Evaluation in 2014}

\section{Variations of Chlorophyll- $a$ in 2014}

The average concentration of Chlorophyll- $a$ in 2014 was $1.20 \mu \mathrm{g} / \mathrm{L}$, and the highest appeared in July $(1.80 \mu \mathrm{g} / \mathrm{L})$. The monthly changes showed a trend that the content in summer and fall were higher than in spring and winter (Fig. 6). Presumably, Chlorophyll- $a$ was related to the seasonal variation of water temperature [50]. Because the climate of Liuzhou is subtropical monsoon, a prevailing southern wind in summer results in high temperatures, humidity, and rain, but a northern wind in winter results in low temperatures and little rain. In the longitudinal changes, the concentrations of Chlorophyll- $a$ in S7 and S8 were higher than others sites, which we can attribute to the abundant nutrients, mostly from urban sources.

Generally, the Chlorophyll- $a$ concentration, representing the phytoplankton biomass, may be controlled by different physical and chemical factors under different conditions [51]. In this study, Chlorophyll- $a$ was predominantly related to water temperature, $\mathrm{DO}, \mathrm{COD}_{\mathrm{Mn}}$, $\mathrm{TN}, \mathrm{NH}_{4}-\mathrm{N}$, and TP (Table 4). The high linear relationship between Chlorophyll-a and water temperature indicates that temperature greatly determined the number of algae. At the same time, the relationship between Chlorophyll- $a$ and the $\mathrm{COD}_{\mathrm{Mn}}, \mathrm{TN}, \mathrm{NH}_{4}-\mathrm{N}$, and TP indicates the influence of domestic sewage effluent from Liuzhou.

\section{Nutritional Status Evaluation in 2014}

This part selected Chlorophyll- $a, \mathrm{COD}_{\mathrm{Mn}}$, TP, and $\mathrm{TN}$ as eutrophication evaluation indices, and the eutrophication state in different months and sampling sites of the Liujiang River in 2014 are shown in Fig. 7. In time scales: in June, the eutrophication level was the highest, and the eutrophication level in the Liujaing was generally mesotrophic except December. This showed a trend that increased and then decreased, and the Chlorophyll- $a$ concentration also had the same trend, mainly because of the water temperature. At the same time, the abundant flow with a large number of pollutants is also a reason for the high $\operatorname{TLI}\left(\sum\right)$ value in June and July. In spatial scales,

Table 4. Person correlation coefficients between water parameters for eight stations in the Liujiang River in 2014.

\begin{tabular}{|c|c|c|c|c|c|c|c|c|}
\hline & $\mathrm{WT}$ & $\mathrm{DO}$ & $\mathrm{pH}$ & $\mathrm{COD}_{\mathrm{Mn}}$ & $\mathrm{TP}$ & $\mathrm{TN}$ & $\mathrm{NH}_{4}-\mathrm{N}$ & Chlorophyll- $a$ \\
\hline $\mathrm{WT}$ & 1.000 & & & & & & & \\
\hline $\mathrm{DO}$ & -0.332 & 1.000 & & & & & & \\
\hline $\mathrm{pH}$ & -0.215 & 0.113 & 1.000 & & & & & \\
\hline $\mathrm{COD}_{\mathrm{Mn}}$ & 0.303 & -0.252 & -0.184 & 1.000 & & & & \\
\hline $\mathrm{TP}$ & 0.154 & -0.219 & -0.270 & 0.141 & 1.000 & & & \\
\hline $\mathrm{TN}$ & 0.275 & -0.092 & -0.062 & 0.543 & 0.025 & 1.000 & & \\
\hline $\mathrm{NH}_{4}-\mathrm{N}$ & 0.127 & -0.101 & -0.086 & 0.678 & 0.067 & 0.561 & 1.000 & \\
\hline Chlorophyll-a & $\mathbf{0 . 6 1 2}$ & $\mathbf{- 0 . 3 4 5}$ & -0.077 & $\mathbf{0 . 5 0 5}$ & $\mathbf{0 . 3 1 8}$ & $\mathbf{0 . 4 2 3}$ & $\mathbf{0 . 5 0 1}$ & 1.000 \\
\hline
\end{tabular}

Values in bold have significant correlation at the 0.01 level (2-tailed), $\mathrm{n}=96$. 

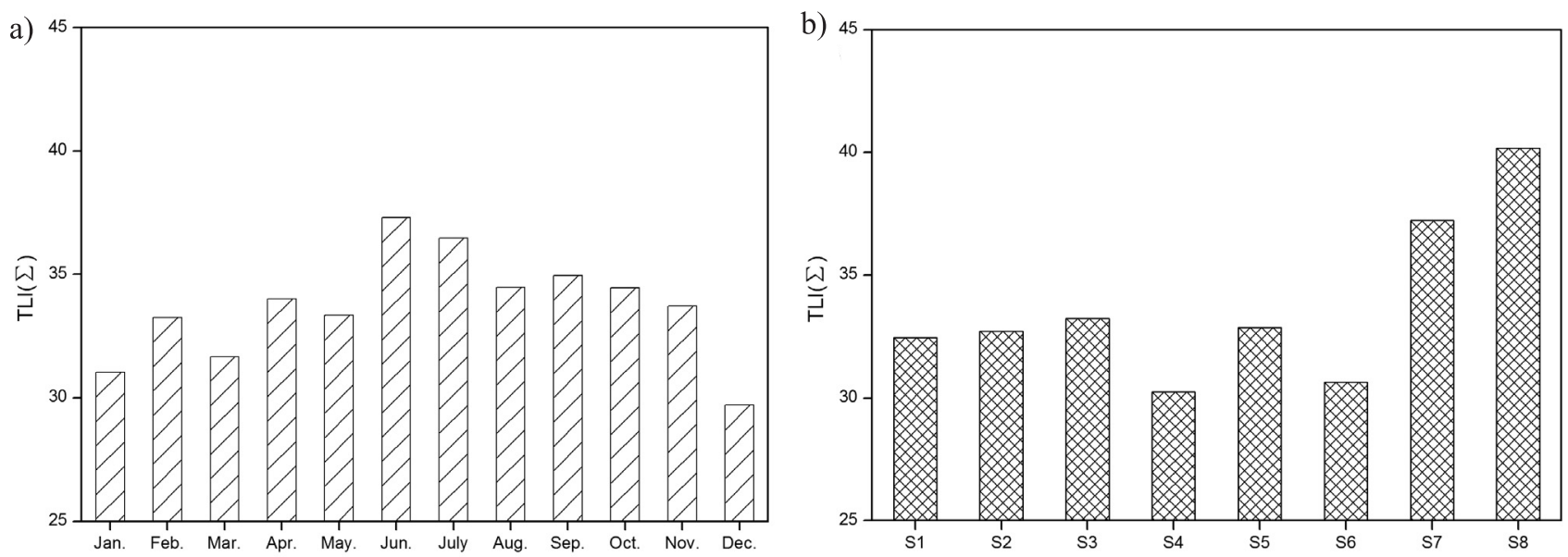

Fig. 7. Eutrophication state in different months a) and sampling sites b) of the Liujiang River in 2014.

the water in S7 and S8 had the highest eutrophication extent due to the location downstream, where lots of nutrients converged. While the water areas in S4 and S6 had the lowest eutrophication extent because of the urban municipal regulation. This indicates that the body of water near S7 and S8 has the biggest risk of algal bloom outbreak.

\section{Nutritional Status Evaluation from 2003 to 2014}

By combining obtained data from 2003 to 2014, this study selected $\mathrm{COD}_{\mathrm{Mn}}$, TP, and $\mathrm{TN}$ as eutrophication evaluation indices, and the analysis results of the eutrophication levels in different regions are shown in Fig. 8. The $\operatorname{TLI}\left(\sum\right)$ of the Liujiang were between 30-50, which indicate that the eutrophication state of the whole river was mesotrophic. In spatial scales, $\operatorname{TLI}\left(\sum\right)$ in the lower river were higher than the other two, which demonstrated that the water area near the lower river had the highest eutrophication extent due to a higher

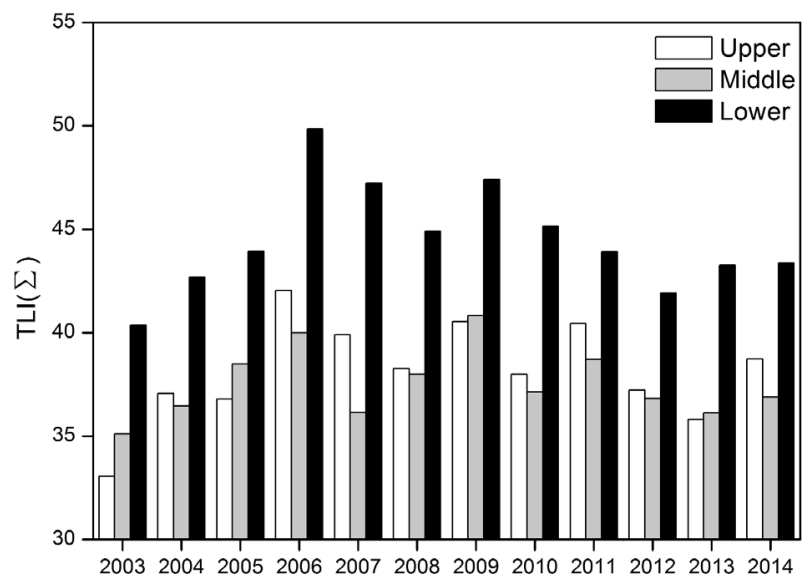

Fig. 8. Eutrophication state in different regions of the Liujiang River from 2003 to 2014. concentration of nutrients. The value was approaching eutrophic level as per the same nutrition state, the higher index value, and the heavier nutrition level. This indicates that the lower river had the biggest risk of algal bloom outbreak in the three water areas.

In time scales, the $\operatorname{TLI}\left(\sum\right)$ in the lower river of 2006 was highest in those years than 2009, which may be related to water storage of the Liujiang River in 2006; at the same time, the rapid development in industry and the quick growth in population impacted river quality, which led to large amounts of sewage. In recent years the TLI $\left(\sum\right)$ values decreased, which suggested that the environmental protection consciousness of citizens was enhanced and factories observed the sewage discharging standard.

\section{Conclusions}

The annual averages of water temperature, $\mathrm{DO}, \mathrm{pH}$, $\mathrm{TN}, \mathrm{NH}_{4}-\mathrm{N}, \mathrm{TP}$, and $\mathrm{COD}_{\mathrm{Mn}}$ were $22.1^{\circ} \mathrm{C}, 7.8 \mathrm{mg} / \mathrm{L}$, 7.58, $1.35 \mathrm{mg} / \mathrm{L}, 0.27 \mathrm{mg} / \mathrm{L}, 0.06 \mathrm{mg} / \mathrm{L}$, and $1.7 \mathrm{mg} / \mathrm{L}$, respectively, in the Liujiang River. In the longitudinal changes, the water temperature was basically similar. The DO levels dropped gradually along the river and the $\mathrm{pH}$ was weakly alkaline as a whole. The concentrations of $\mathrm{TN}, \mathrm{NH}_{4}-\mathrm{N}$, and TP downstream were obviously higher than other stations, and it was more inclined to phosphorus restricted in the molar TN/TP ratio. On the whole, the annual average concentrations of these seven parameters had reached standard III, except TN, so the control of nitrogen emissions should be strengthened.

The interannual variations of the three parts of the Liujiang River showed that the water temperature in the middle Liujiang was obviously lower than other parts, and the $\mathrm{pH}$ in three sections all had a conspicuous trend of acidification. The TN was rising on the whole due to pollution from industry joint in agriculture, while $\mathrm{NH}_{4}-\mathrm{N}$, $\mathrm{TP}$, and $\mathrm{COD}_{\mathrm{Mn}}$ were changeable without an obvious trend. The concentrations of nutrient salts are higher in the lower Liujiang than other parts because of the anthropogenic influence, and the values of nutrients in 2006 were high 
because the Honghua dam began to impound water at the end of 2005, and then the pollutants in the city were blocked and accumulated.

Water quality parameters, especially $\mathrm{pH}$ and $\mathrm{TN}$, were significantly correlated with local GDP and population. The average concentrations of Chlorophyll- $a$ in 2014 were $1.2 \mu \mathrm{g} / \mathrm{L}$ and the highest appeared in July, showing that Chlorophyll- $a$ was related to the seasonal variation of water temperature. The eutrophication state of the Liujiang was mesotrophic on the whole. In a hydrological year the highest TLI $\left(\sum\right)$ value appeared in June, while the annual $\operatorname{TLI}\left(\sum\right)$ values decreased from 2006. Furthermore, the water in the lower Liujiang River has the higher risk of algal bloom outbreak than the other parts of the river. The concentrations of nutrients in the Liujiang were at low levels compared with others rivers.

\section{Acknowledgements}

This work was supported by the National Key Basic Research Program of China (2013CB956102), the NSFC (41473118, 41506146, 41273139), the Program of Liuzhou Government (LZG13-401) and the BaGui Scholars Program Foundation (2014).

\section{References}

1. DRIVER N.E., TROUTMAN B.M. Regression models for estimating urban storm-runoff quality and quantity in the United States. Journal of Hydrology 109, 221, 1989.

2. BRILLY M., RUSJAN S., VIDMAR A. Monitoring the impact of urbanisation on the Glinscica stream. Physics and Chemistry of the Earth 31, 1089, 2006.

3. OSTOJIĆ I., TOPUZOVIĆ M., ČOMIĆ L., ĆURČIĆ S. Long-Term Changes in Some Chemical and Biological Characteristics of the Grošnica Reservoir Water, Serbia. Polish Journal of Environmental Studies. 18 (4), 681, 2009.

4. HU J., QIAO Y., ZHOU L., LI S. Spatiotemporal distributions of nutrients in the downstream from Gezhouba Dam in Yangtze River, China. Environ Sci Pollut R. 19 (7), 2849, 2012.

5. NAPIÓRKOWSKA-KRZEBIETKE A., STAWECKI K., PYKA J.-P., HUTOROWICZ J., ZDANOWSKI B. Phytoplankton in Relation to Water Quality of a Mesotrophic Lake. Polish Journal of Environmental Studies. 22 (3), 793, 2013.

6. MATYSIK M., ABSALON D., RUMAN M. Surface Water Quality in Relation to Land Cover in Agricultural Catchments (Liswarta River Basin Case Study). Polish Journal of Environmental Studies. 24 (1), 175, 2015.

7. LIANDONG JING, HONGYI AO, XIAOLONG HUANG, XIONG XIONG, CHENXI WU, JIANTONG LIU. Water Environment Characteristics at Taige Canal-Taihu Lake: a Comparative Study on Interaction between Chlorophyll- $a$ and Environmental Variables. Polish Journal of Environmental Studies. 24 (3), 1031, 2015.

8. PASZTALENIEC A., KUTYŁA S. The Ecological Status of Lakes in National and Landscape Parks: Does the Location of a Lake and Its Catchment within a Protected Area Matter? Polish Journal of Environmental Studies. 24 (1), 227, 2015.
9. DAI H.C., MAO J.Q., JIANG D.G., WANG L.L. Longitudinal hydrodynamic characteristics in reservoir tributary embayments and effects on algal blooms. PLoS One. 8, 1, 2013

10. YANG Z.J., LIU D.F., JI D.B., XIAO S.B. Influence of the impounding process of the Three Gorges Reservoir up to water level $172.5 \mathrm{~m}$ on water eutrophication in the Xiangxi Bay. Sci. China Technol. Sci. 53, 358, 2010.

11. MA F., LI C., WANG X., YANG Z., SUN C., LIANG P. A Bayesian method for comprehensive water quality evaluation of the Danjiangkou Reservoir water source area, for the middle route of the South-to-North Water Diversion Project in China. FRONT EARTH SCI-PRC. 8 (2), 242, 2014.

12. XIAOMING CHUAI, HAIXIA ZHOU, XIAOFENG CHEN, LIUYAN YANG, JIN ZENG. Effects of Different Primary Producers (Cyanobacteria and Macrophyte) on the Spatio-Temporal Distribution of Phosphorus Forms and Concentrations in a Lake. Polish Journal of Environmental Studies. 22 (6), 1649, 2013.

13. DODDS W.K., WELCH E.B. Establishing Nutrient Criteria in Streams. Journal of the North American Benthological Society 19, 186, 2000.

14. SMITH V.H., JOYE S.B., HOWARTH R.W. Eutrophication of Freshwater and Marine Ecosystems. Limnology and Oceanography 51, 351, 2006.

15. Paerl H.W.. Controlling Eutrophication along the FreshwaterMarine Continuum: Dual Nutrient (N and P) Reductions Are Essential. Estuaries and Coasts 32, 593, 2009.

16. BALCERZAK W. The Protection of Reservoir Water against the Eutrophication Process. Polish Journal of Environmental Studies. 15 (6), 837, 2006.

17. SOBCZYŃSKI T., JONIAK T. The Variability and Stability of Water Chemistry in a Deep Temperate Lake: Results of Long-Term Study of Eutrophication. Polish Journal of Environmental Studies. 22 (1), 227, 2013.

18. LV H., YANG J., LIU L., YU X., YU Z., CHIANG P. Temperature and nutrients are significant drivers of seasonal shift in phytoplankton community from a drinking water reservoir, subtropical China. Environ Sci Pollut R. 21 (9), 5917, 2014.

19. HUANG Y., ZHANG P., LIU D., YANG Z., JI D. Nutrient spatial pattern of the upstream, mainstream and tributaries of the Three Gorges Reservoir in China. ENVIRON MONIT ASSESS. 186 (10), 6833, 2014.

20. LIAN J., YAO Y., MA C., GUO Q. Reservoir Operation Rules for Controlling Algal Blooms in a Tributary to the Impoundment of Three Gorges Dam. WATER-SUI. 6 (10), 3200, 2014

21. LIU Y. Water function zone current status evaluation for Liujiang River section within Liuzhou City, Guangxi water resources and hydropower engineering. 06, 56, 2013.

22. CHENG Q., MENG L., YI Y., XU J. Ecosystem Survey of Zoobenthos in the Cantonal of Liujiang, Journal of Anhui Agricultural Science. 17, 9048, 2010.

23. ZHOU Y., ZHI C., WANG L., YOU Q. Health Risk Assessment of Heavy Metals Pollution in Liujiang River, Journal of Anhui Agricultural Science. 41 (10), 4370, 2013.

24. XU M.J., YU L., ZHAO Y.W., LI M. The Simulation of Shallow Reservoir Eutrophication Based on MIKE21: A Case Study of Douhe Reservoir in North China. Procedia Environmental Sciences. 13, 1975, 2012.

25. GUO Q. Hebei University of Engineering, The research on flow characteristics and dissolved oxygen of urban river bottomland. 79, 2015.

26. SU C. Yangzhou University, Research on typical waste dissolved oxygen distribution characteristics of Yangzhou 
and oxygen-rich technology. 97, 2011.

27. ZHAO W., CAI Z.C., XU Z.H. Does ammonium-based N addition influence nitrification and acidification in humid subtropical soils of China? Plant Soil. 297, 213, 2007.

28. GUO J.H., LIU X.J., ZHANG Y., SHEN J.L., HAN W.X., ZHANG W.F., CHRISTIE P., GOULDING K.W., VITOUSEK P.M., ZHANG F.S. Significant acidification in major Chinese croplands. Science. 327, 1008, 2010.

29. VIEIRA F., BAYER C., MIELNICZUK J., ZANATTA J., BISSANI C.A. Long-term acidification of a Brazilian Acrisol as affected by no till cropping systems and nitrogen fertiliser. Aust J Soil Res 46, 17, 2008.

30. RUSSELL AELD. Nitrogen fertilization and cropping system impacts on soil quality in Midwestern Mollisols. Soil Sci Soc Am J. 1, 249, 2006.

31. REDFIELD A.C., KETCHUM B.H., RICHARDS F.A. The influence of organisms on the composition of seawater. In: Hill, M.N. (Ed.), the Sea, Wiley Interscience, New York, 2, 26, 1963

32. YANG D., YANG X. The Influence of Tides and Earthquakes in Global Climatic Changes. Desert and Oasis Meteorology. 04, 5, 2007.

33. ZHIQING X., YIN D.U., YAN Z., YACHUN L.I., JINGANG W.U., SHENGMING J. Impact of Spatio-temporal Variation of Precipitation on Severe Acid Rain in Southern China. ACTA GEOGRAPHICA SINICA. 63 (9), 913, 2008.

34. DU Y., LIANG J., LIANG J. Analysis of acid rain regional distribution and variation in Guangxi based on Gis. Environmental engineering. S2, 371, 2012.

35. XU P.Z., QIN B.Q., HORST B., HUANG W.Y., YU M.S., ZHANG Y.P. Nitrogen surplus of the upstream agricultural land of Lake Taihu and the eutrophication impact[J]. Journal of Lake Sciences. 04, 395, 2006.

36. JIN M., REN Z., SHI J.P., HUANG X.Z., CHEN J.R. Impact of Agricultural Non-point Source Pollution in Eutrophic Water Body of Taihu Lake [J]. Environmental Science \& Technology. 33 (10), 106, 119, 2010.

37. ZHANG Y., GAO X., ZHANG H. Association Study Between Water Quality of Chaohu Lake and Resources Input in Agriculture of Basin [J]. Environmental Science. 09, 3009, 2012.

38. CHEN X.F., CHUAI X.M., YANG L.Y. Status Quo, Historical Evolution and Causes of Eutrophication in Lakes in Typical Lake Regions of China[J]. Journal of Ecology and rural Environment. 04, 438, 2014.

39. GROBBELAAR J.U., HOUSE W.A. Phosphorus as a limiting resource in inland waters; Interactions with nitrogen. In: Tiessen, H. (Ed.), Phosphorus in the Global Environment: Transfers, Cycles and Management. John Wiley and Sons, New York, SCOPE 54, 16, 1995.
40. GAO Y.X., CAI L.L., ZHAO L.L., ZHU G.W. Water Quality Comparison Between Lake Taihu and Contribute River During High Water-level Period. Environmental Science 32 (10), 2840, 2011.

41. ZHENG B.H., CAO C.J., QIN Y.W., HUANG M.S. Analysis of Nitrogen Distribution Characters and Their Sources of the Major Input Rivers of Three Gorges Reservoir. Environmental Science 29 (01), 1, 2008 [in Chinese].

42. CAO C.J., QIN Y.W., ZHENG B.H., HUANG M.S. Analysis of Phosphorus Distribution Characters and Their Sources of the Major Input Rivers of Three Gorges Reservoir. Environmental Science 29 (02), 2310, 2008 [in Chinese].

43. WANG Q. The Analysis of Current Status and Changes of Water Quality of Fenhe River's Taiyuan Section. Sci-Tech Information Development and Economy 18 (29), 100, 2008. [in Chinese].

44. LIN X.J., ZHU C.M., TAN L. Dynamic Analysis of Water Quality in Changsha Part of Xiang River from 2000 to 2005. Practical Preventive Medicine 15 (04), 1122, 2008 [in Chinese].

45. LEI G.Y., YANG Y.F., WANG Q., HU R., WANG C.H. Characteristics of Water Quality and Phytoplankton community in the Guangzhou Segment of the River Pearl. Journal of Jinan University (Natural Science) 28 (03), 302, 2007 [in Chinese].

46. ZHAO N., LIU Y., CHEN J.N., YAN X. Comparative Analysis on Basin in Water Pollution Control-Huai River with Rhine, Danube River. Environment Science and Management 34 (09), 6, 2009 [in Chinese].

47. COLIN N., RICHARD J.W., MARGARET N., LAL C.B., HEATHER W., MARTIN H., LINDA K.H., The water quality of the River Thames at a rural site downstream of Oxford. The Science of the Total Environment, 251/252, 441, 2000b.

48. GARNIER J., NÉMERY J., BILLEN G., THÉRY S. Nutrient dynamics and control of eutrophication in the Marne River system: modelling the role of exchangeable phosphorus. Journal of Hydrology 304 (1-4), 397, 2005.

49. MINAUDO C., MOATAR F., MEYBECK M., CURIE F., GASSAMA N., LEITAO M. Loire River eutrophication mitigation (1981-2011) measured by seasonal nutrients and algal pigments. Joint Assembly of IAHS, IAPSO and IASPEI 361, 167, 2013.

50. JIANG D.G., DAI H.C., LIU W. Influence of thermal density flow on hydrodynamics of Xiangxi Bay in Three Georges Reservoir, China. Procedia Environ. Sci. 10, 1637, 2011.

51. WEI P., HUANG L. Water quality and eutrophication in the Guangzhou Sea Zone of the Pearl River estuary. Chin J Oceanol Limn, 28 (1), 113, 2010. 